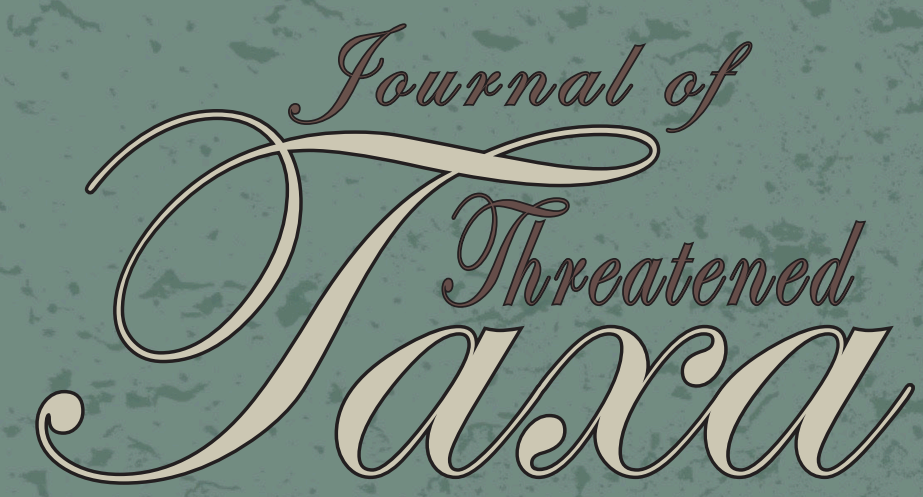

Building evidence for conservation globally
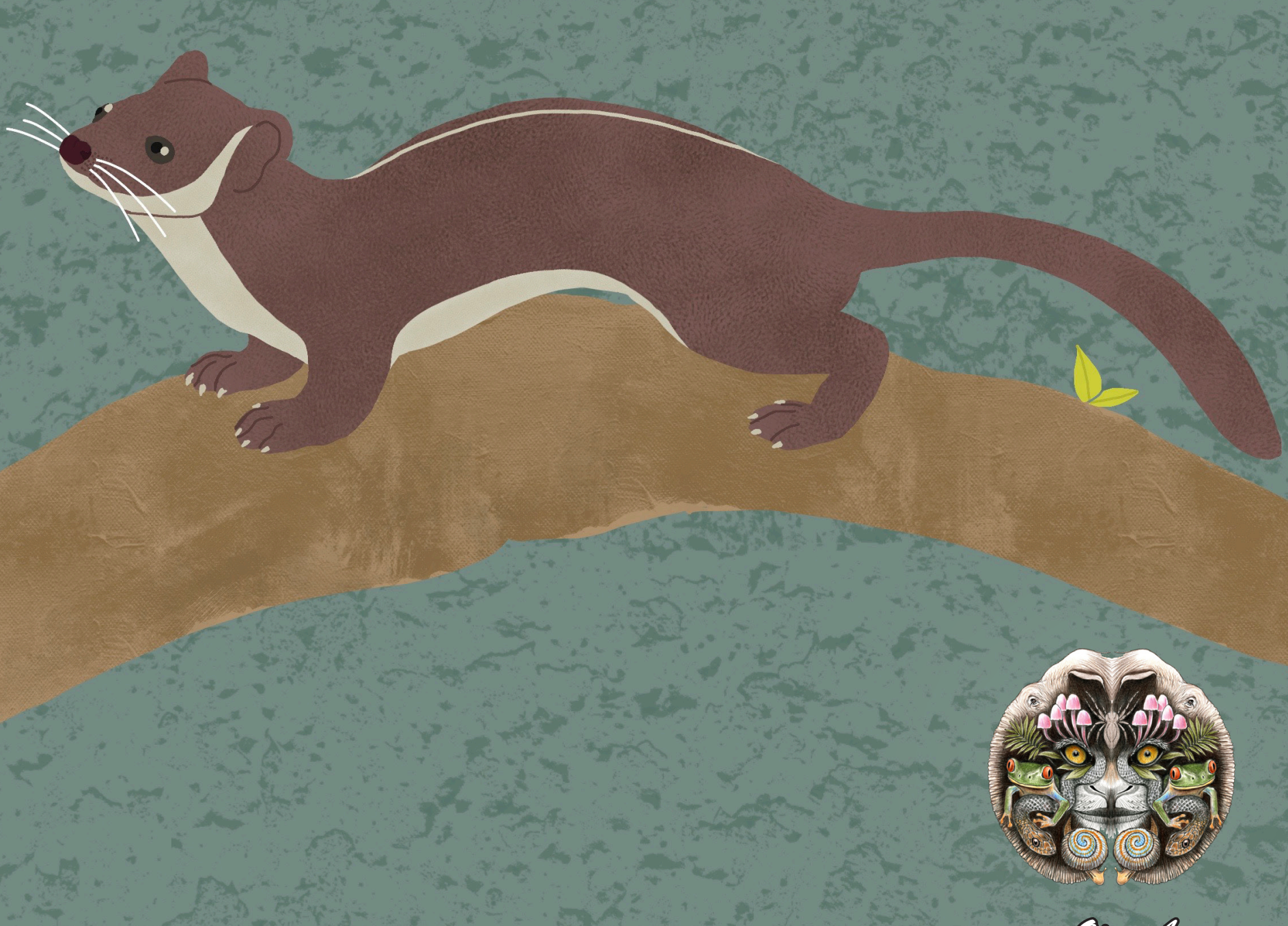

Qpecosecess

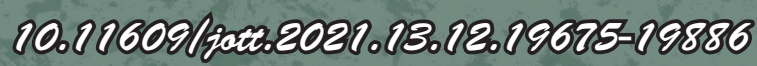
cocosurthreatecredtassararg

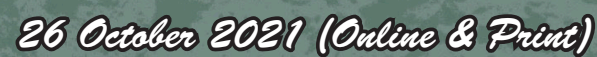

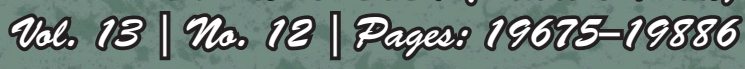




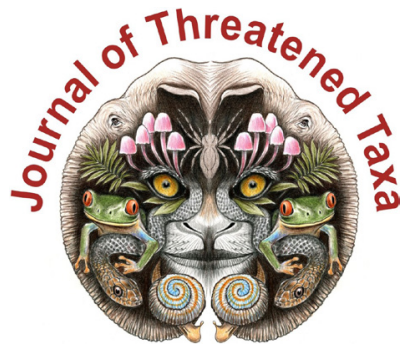

ISSN 0974-7907 (Online); ISSN $0974-7893$ (Print)

Publisher

Host

Wildlife Information Liaison Development Society

www.wild.zooreach.org

Zoo Outreach Organization www.zooreach.org

No. 12, Thiruvannamalai Nagar, Saravanampatti - Kalapatti Road, Saravanampatti, Coimbatore, Tamil Nadu 641035, India

Ph: +91 9385339863 | www.threatenedtaxa.org

Email: sanjay@threatenedtaxa.org

EDITORS

\section{Founder \& Chief Editor}

Dr. Sanjay Molur

Wildlife Information Liaison Development (WILD) Society \& Zoo Outreach Organization (ZOO)

12 Thiruvannamalai Nagar, Saravanampatti, Coimbatore, Tamil Nadu 641035, India

\section{Deputy Chief Edito}

Dr. Neelesh Dahanukar

Noida, Uttar Pradesh, India

\section{Managing Editor}

Mr. B. Ravichandran, WILD/ZOO, Coimbatore, India

\section{Associate Editors}

Dr. Mandar Paingankar, Government Science College Gadchiroli, Maharashtra 442605, India Dr. Ulrike Streicher, Wildlife Veterinarian, Eugene, Oregon, USA

Ms. Priyanka Iyer, ZOO/WILD, Coimbatore, Tamil Nadu 641035, India

Dr. B. A. Daniel, $200 /$ WIID, Coimbatore, Tamil Nadu 641035, India

\section{Editorial Board}

Dr. Russel Mittermeie

Executive Vice Chair, Conservation International, Arlington, Virginia 22202, USA

\section{Prof. Mewa Singh Ph.D., FASc, FNA, FNASc, FNAPsy}

Ramanna Fellow and Life-Long Distinguished Professor, Biopsychology Laboratory, and Institute of Excellence, University of Mysore, Mysuru, Karnataka 570006, India; Honorary Professor, Jawaharlal Nehru Centre for Advanced Scientific Research, Bangalore; and Adjunct Professor, National Institute of Advanced Studies, Bangalore

\section{Stephen D. Nash}

Scientific Illustrator, Conservation International, Dept. of Anatomical Sciences, Health Sciences Center, T-8, Room 045, Stony Brook University, Stony Brook, NY 11794-8081, USA

\section{Dr. Fred Pluthero}

Toronto, Canada

\section{Dr. Priya Davidar}

Sigur Nature Trust, Chadapatti, Mavinhalla PO, Nilgiris, Tamil Nadu 643223, India

\section{Dr. Martin Fisher}

Senior Associate Professor, Battcock Centre for Experimental Astrophysics, Cavendish

Laboratory, JJ Thomson Avenue, Cambridge CB3 OHE, UK

\section{Dr. John Fellowes}

Honorary Assistant Professor, The Kadoorie Institute, 8/F, T.T. Tsui Building, The University of Hong Kong, Pokfulam Road, Hong Kong

\section{Prof. Dr. Mirco Solé}

Universidade Estadual de Santa Cruz, Departamento de Ciências Biológicas, Vice-coordenado do Programa de Pós-Graduação em Zoologia, Rodovia Ilhéus/Itabuna, Km 16 (45662-000)

Salobrinho, Ilhéus - Bahia - Brasil

\section{Dr. Rajeev Raghavan}

Professor of Taxonomy, Kerala University of Fisheries \& Ocean Studies, Kochi, Kerala, India

\section{English Editors}

Mrs. Mira Bhojwani, Pune, India

Dr. Fred Pluthero, Toronto, Canad

Mr. P. Ilangovan, Chennai, India

Web Maintenance

Mrs. Latha G. Ravikumar, ZOO/WILD, Coimbatore, India

\section{Typesetting}

Mr. Arul Jagadish, ZOO, Coimbatore, India

Mrs. Radhika, ZOO, Coimbatore, India

Mrs. Geetha, ZOO, Coimbatore India

\section{Fundraising/Communications}

Mrs. Payal B. Molur, Coimbatore, India

Subject Editors 2018-2020

Fungi

Dr. B. Shivaraju, Bengaluru, Karnataka, India

Dr. R.K. Verma, Tropical Forest Research Institute, Jabalpur, India

Dr. Vatsavaya S. Raju, Kakatiay University, Warangal, Andhra Pradesh, India

Dr. M. Krishnappa, Jnana Sahyadri, Kuvempu University, Shimoga, Karnataka, India

Dr. K.R. Sridhar, Mangalore University, Mangalagangotri, Mangalore, Karnataka, India

Dr. Gunjan Biswas, Vidyasagar University, Midnapore, West Bengal, India

Plants

Dr. G.P. Sinha, Botanical Survey of India, Allahabad, India

Dr. N.P. Balakrishnan, Ret. Joint Director, BSI, Coimbatore, India

Dr. Shonil Bhagwat, Open University and University of Oxford, UK

Prof. D.J. Bhat, Retd. Professor, Goa University, Goa, India

Dr. Ferdinando Boero, Università del Salento, Lecce, Italy

Dr. Dale R. Calder, Royal Ontaro Museum, Toronto, Ontario, Canada

Dr. Cleofas Cervancia, Univ. of Philippines Los Baños College Laguna, Philippines

Dr. F.B. Vincent Florens, University of Mauritius, Mauritius

Dr. Merlin Franco, Curtin University, Malaysia

Dr. V. Irudayaraj, St. Xavier's College, Palayamkottai, Tamil Nadu, India

Dr. B.S. Kholia, Botanical Survey of India, Gangtok, Sikkim, India

Dr. Pankaj Kumar, Kadoorie Farm and Botanic Garden Corporation, Hong Kong S.A.R., China

Dr. V. Sampath Kumar, Botanical Survey of India, Howrah, West Bengal, India

Dr. A.J. Solomon Raju, Andhra University, Visakhapatnam, India

Dr. Vijayasankar Raman, University of Mississippi, USA

Dr. B. Ravi Prasad Rao, Sri Krishnadevaraya University, Anantpur, India

Dr. K. Ravikumar, FRLHT, Bengaluru, Karnataka, India

Dr. Aparna Watve, Pune, Maharashtra, India

Dr. Qiang Liu, Xishuangbanna Tropical Botanical Garden, Yunnan, China

Dr. Noor Azhar Mohamed Shazili, Universiti Malaysia Terengganu, Kuala Terengganu, Malaysia Dr. M.K. Vasudeva Rao, Shiv Ranjani Housing Society, Pune, Maharashtra, India

Prof. A.J. Solomon Raju, Andhra University, Visakhapatnam, India

Dr. Mandar Datar, Agharkar Research Institute, Pune, Maharashtra, India

Dr. M.K. Janarthanam, Goa University, Goa, India

Dr. K. Karthigeyan, Botanical Survey of India, India

Dr. Errol Vela, University of Montpellier, Montpellier, France

Dr. P. Lakshminarasimhan, Botanical Survey of India, Howrah, India

Dr. Larry R. Noblick, Montgomery Botanical Center, Miami, USA

Dr. K. Haridasan, Pallavur, Palakkad District, Kerala, India

Dr. Analinda Manila-Fajard, University of the Philippines Los Banos, Laguna, Philippines

Dr. P.A. Sinu, Central University of Kerala, Kasaragod, Kerala, India

Dr. Afroz Alam, Banasthali Vidyapith (accredited A grade by NAAC), Rajasthan, India

Dr. K.P. Rajesh, Zamorin's Guruvayurappan College, GA College PO, Kozhikode, Kerala, India

Dr. David E. Boufford, Harvard University Herbaria, Cambridge, MA 02138-2020, USA

Dr. Ritesh Kumar Choudhary, Agharkar Research Institute, Pune, Maharashtra, India

Dr. Navendu Page, Wildlife Institute of India, Chandrabani, Dehradun, Uttarakhand, India

Invertebrates

Dr. R.K. Avasthi, Rohtak University, Haryana, India

Dr. D.B. Bastawade, Maharashtra, India

Dr. Partha Pratim Bhattacharjee, Tripura University, Suryamaninagar, India

Dr. Kailash Chandra, Zoological Survey of India, Jabalpur, Madhya Pradesh, India

Dr. Ansie Dippenaar-Schoeman, University of Pretoria, Queenswood, South Africa

Dr. Rory Dow, National Museum of natural History Naturalis, The Netherlands

Dr. Brian Fisher, California Academy of Sciences, USA

Dr. Richard Gallon, llandudno, North Wales, LL30 1UP

Dr. Hemant V. Ghate, Modern College, Pune, India

Dr. M. Monwar Hossain, Jahangirnagar University, Dhaka, Bangladesh

Mr. Jatishwor Singh Irungbam, Biology Centre CAS, Branišovská, Czech Republic.

Dr. lan J. Kitching, Natural History Museum, Cromwell Road, UK

Dr. George Mathew, Kerala Forest Research Institute, Peechi, India

Dr. John Noyes, Natural History Museum, London, UK

For Focus, Scope, Aims, and Policies, visit https://threatenedtaxa.org/index.php/JoTT/aims_scope
For Article Submission Guidelines, visit https://threatenedtaxa.org/index.php/JoTT/about/submissions
For Policies against Scientific Misconduct, visit https://threatenedtaxa.org/index.php/JoTT/policies_various

continued on the back inside cover 


\title{
Field identification characters to diagnose Microhyla mukhlesuri from closely related $M$. mymensinghensis (Amphibia: Microhylidae) and range extension of M. mukhlesuri up to West Bengal State, India
}

\author{
Suman Pratihar ${ }^{1}$ (D) \& Kaushik Deuti $^{2}$ (D) \\ ${ }^{1}$ Department of Zoology, Sukumar Sengupta Mahavidyalaya, Keshpur, West Bengal 721150, India. \\ ${ }^{2}$ Zoological Survey of India, Herpetology Division, 27 JL Nehru Road, Kolkata, West Bengal 700016, India. \\ ${ }^{1}$ pratihar_vu@rediffmail.com (corresponding author), ${ }^{2}$ kaushikdeuti@gmail.com
}

\begin{abstract}
Microhyla mymensinghensis and Microhyla mukhlesuri were recorded from West Bengal, also analyzed 12 characters to separate the species. We also hereby first time confirm the presence of Microhyla mukhlesuri from the main land in India
\end{abstract}

Keywords: Amphibia, first record, frogs.

Twenty-seven species have been described within the last 15 years (Frost 2021), yet Microhyla remains one of the most taxonomically exciting groups of Asian frogs. Microhylidae is one of the most species rich family of Anura, comprising 690 species in 12 subfamilies (Frost 2020). Previous mitochondrial phylogenies have confirmed that Microhyla mukhlesuri Hasan, Islam, Kuramoto, Kurabayashi \& Sumida, 2014 is sister to M. fissipes Boulenger, 1884 and that together they are sister to $M$. mymensinghensis Hasan, Islam, Kuramoto, Kurabayashi \& Sumida, 2014 (Hasan et al. 2014; Howlader et al. 2016; Yuan et al. 2016). Asian congeners, M. chakrapanii Pillai, 1977, M. mukhlesuri, and $M$. mymensinghensis are nested along with $M$. fissipes Boulenger, 1884 and together these four species are the sister group to the clade containing $M$. mixtura and M. okinavensis (Garg et al. 2019). The M. fissipes species group consists of two subclades (Poyarkov et al. 2019). Clade one species reported from Laos, Thailand, Myanmar, Philippines, Singapore, southrn Asia, and the Andamans ( $M$. fissipes, M. mukhlesuri, $M$. mymensinghensis, $M$. chakrapanii). And the other clade comprising species from mainland China (Garg et al. 2019).

Microhyla mymensinghensis was first described from Mymensingh, Bangladesh together with M. mukhlesuri (see Hasan et al. 2014). Microhyla mymensinghensis was recorded from Manipur, Meghalaya, Nagaland, Tripura, and West Bengal in India. But $M$. mukhlesuri has been listed only from Mizoram state in the northeastern India (Garg et al. 2019). No details were reported to confirm the finding. Our study confirms the presence of both species in West Bengal, by analyzing 16 morphometric characters to separate these species. We also hereby confirm the presence of Microhyla mukhlesuri from

Citation: Pratihar, S. \& K. Deuti (2021). Field identification characters to diagnose Microhyla mukhlesuri from closely related M. mymensinghensis (Amphibia: Microhylidae) and range extension of M. mukhlesuri up to West Bengal State, India. Journal of Threatened Taxa 13(12): 19818-19823. https://doi.org/10.11609/ jott.7384.13.12.19818-19823

Copyright: @ Pratihar \& Deuti 2021. Creative Commons Attribution 4.0 International License. JoTT allows unrestricted use, reproduction, and distribution of this article in any medium by providing adequate credit to the author(s) and the source of publication.

Funding: None.

Competing interests: The authors declare no competing interests.

Acknowledgements: SP wishes to thank the principal of Keshpur College for this study while KD wishes to thank Dr. Kailash Chandra, Director, Zoological Survey of India for use of laboratory facilities like microscope and magnanoscope. We also like to thank to Dr. Nirupam Acharya, Vidyasagar University for his help regarding preparation of the map. We thank Debayan Gayen, junior research fellow, ZSI canning station, WB for doing the PCA analysis. 
the Gangetic Plain of West Bengal in India, as it was described from Bangladesh (Hasan et al. 2014).

\section{MAterials AND MethodS}

Field work was conducted during late evening in the months of May-July 2020 in Kharagpur, Medinipur Sadar $\left(22.2500^{\circ} \mathrm{N}, 87.6500^{\circ} \mathrm{E}\right)$, Ghatal and Jhargram $\left(22.0559^{\circ} \mathrm{N}, 87.1518^{\circ} \mathrm{E}\right)$ areas of West Midnapore district in the state of West Bengal, India. Habitats searched included marshes, pools, riverbanks and sandy soils inside grass, leaf litter and under boulders. Morphometric and meristic studies on the preserved specimens were done at the laboratory of the Herpetology Division, Zoological Survey of India, Kolkata using a LEICA EZ-4 stereo binocular microscope and a Heerburg magnanoscope. Measurements were done with Mitutoyo Digital caliper to the nearest $0.1 \mathrm{~mm}$. Four specimens were collected (ZSI A 14818, ZSI A 14819, ZSI A 14871 and ZSI A 14872) and identified as Microhyla mukhlesuri (Image 1a, Table 1a). Five specimens were collected (ZSI A 14680, ZSI A 14681, ZSI A 14682, ZSI A 14873 and ZSI A 14874) and identified as Microhyla mymensinghensis (Image 1b, Table 1b). We found no Microhyla ornata in the sampling site (Midnapore, West Bengal) during our survey.

For species-level analysis we examined 16 morphological characters to elucidate species identification (1) Body size (SVL) (2) Head length and head width (HL/HW) (3) extent of Tibiotarsal articulation (4) Shape of Terminal phalanges on toes (5) Shape and size of Inner and outer metatarsal, metacarpal tubercle; (6) Webbing on toes (7) length of femur and tibia (8) Dorsal spotting. (9) extent of Lateral stripe (10) pattern on the anus. (11) FAL= Forearm length, $L A L=$ Lower arm length, $\mathrm{HAL}=$ Hand length, $\mathrm{FAW}=$ Forearm width 12. Axilla-Groin distance (A-G) (Table 1). We also have added HL, HW, FAW, TL and A-G ratios with SVL (Table no 2). We have grouped the species based on characters described by Hassan et al. (2014).

Principal Component Analysis (PCA) was performed on 16 morphometric measurements from specimens of both Microhyla mukhlesuri $(\mathrm{n}=4)$ and Microhyla mymensinghensis $(n=5)$ using PAST 3.0 Software. Before doing the PCA, a normality test was done for all the variables. PCA factor scores for principal components (PC) with eigenvalues $>1.0$ were reported. Factor scores of the first two components were visualized

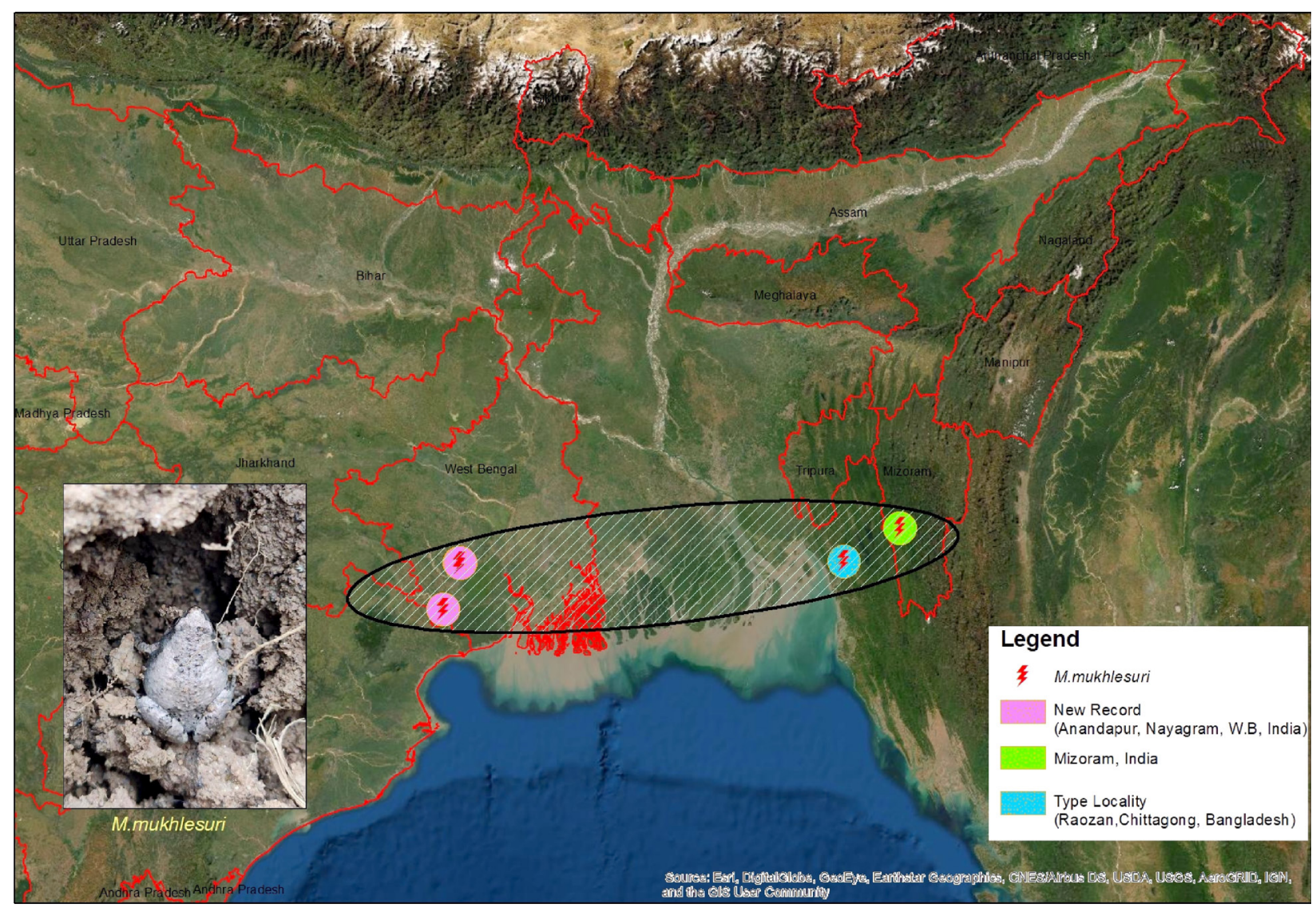

Image 1. Range extension of Microhyla mukhlesuri to West Bengal State. 
Table 1a. Sixteen morphometric character values (in $\mathrm{mm}$ ) for Microhyla mukhlesuri.

\begin{tabular}{|c|c|c|c|c|c|}
\hline $\begin{array}{c}\text { Specimen } \\
\text { No }\end{array}$ & $\begin{array}{c}\text { ZSI A } \\
\mathbf{1 4 8 1 9}\end{array}$ & $\begin{array}{c}\text { ZSI A } \\
\mathbf{1 4 8 1 8}\end{array}$ & $\begin{array}{c}\text { ZSI A } \\
\mathbf{1 4 8 7 1}\end{array}$ & $\begin{array}{c}\text { ZSI A } \\
\mathbf{1 4 8 7 2}\end{array}$ & Mean \\
\hline Sex & male & male & male & female & \\
\hline SVL & 20.86 & 18.92 & 19.84 & 20.76 & 20.09 \\
\hline HL & 4.28 & 4.71 & 3.98 & 3.78 & 4.18 \\
\hline HW & 4.56 & 5.44 & 4.35 & 4.36 & 4.67 \\
\hline SL & 2.39 & 2.57 & 2.27 & 2.58 & 2.45 \\
\hline FAL & 3 & 3.14 & 4.52 & 4.29 & 3.73 \\
\hline LAL & 3.09 & 3.05 & 3.5 & 3.67 & 3.32 \\
\hline HAL & 4.17 & 3.07 & 3.9 & 3.06 & 3.55 \\
\hline FAW & 1.08 & 1.13 & 1.2 & 1.33 & 1.17 \\
\hline IMC & 0.48 & 0.57 & 0.42 & 0.44 & 0.47 \\
\hline OMC & 0.42 & 0.51 & 0.32 & 0.38 & 0.4 \\
\hline A-G & 8.52 & 8.96 & 8.87 & 11.33 & 9.42 \\
\hline FL & 8.15 & 8.23 & 8.18 & 8.41 & 8.24 \\
\hline TL & 10.8 & 9.97 & 10.56 & 10.37 & 10.42 \\
\hline FoL & 9.89 & 10.16 & 9.41 & 9.35 & 9.7 \\
\hline IMT & 0.79 & 0.7 & 0.69 & 0.87 & 0.76 \\
\hline OMT & 0.53 & 0.38 & 0.52 & 0.46 & 0.47 \\
\hline
\end{tabular}

on scatterplots to assess the degree of morphological differentiation between specimens of the two species.

\section{RESULTS}

Two Microhyla species were collected during the present study Microhyla mukhlesuri $(n=4)$ and $M$. mymensinghensis $(n=5)$. The specimens were identified to belong to the genus Microhyla by the following morphological characters: absence of vomerine teeth, hidden tympanum, elliptical tongue, short snout, small eyes not protuberant and invisible from the ventral side, indistinct canthus rostralis and fingers free of webbing. Four specimens were identified as Microhyla mukhlesuri (Image 2a) based on size, extent of tibiotarsal articulation, mark on anus, forearm width, tibia length and shape of terminal phalanges (Garg et al. 2019; Hasan et al. 2014). This is the first record of Microhyla mukhlesuri from entire Gangetic plains of India, West Bengal (Nayagram, $22.0361^{\circ} \mathrm{N}, 87.1717^{\circ} \mathrm{E}$ ) (Image 1) which extends its range by $494 \mathrm{~km}$ from its type locality (Rhozan, Chittagong, Bangladesh) and by $568 \mathrm{~km}$ away from Mizoram, India (which was the only record from India Garg et al. 2019). Whereas M. mymensinghensis (Image $2 b$ ) is identified based on size, tibia length, mark on anus and forearm width (Garg et al. 2019; Hasan et al. 2014). We found $M$. mukhlesuri differs from $M$.
Table 1b. Sixteen morphometric character values (in $\mathrm{mm}$ ) for Microhyla mymensinghensis.

\begin{tabular}{|c|c|c|c|c|c|c|}
\hline $\begin{array}{c}\text { Specimen } \\
\text { No }\end{array}$ & $\begin{array}{c}\text { ZSIA } \\
\mathbf{1 4 6 8 0}\end{array}$ & $\begin{array}{c}\text { ZSIA } \\
\mathbf{1 4 6 8 1}\end{array}$ & $\begin{array}{c}\text { ZSIA } \\
\mathbf{1 4 6 8 2}\end{array}$ & $\begin{array}{c}\text { ZSIA } \\
\mathbf{1 4 8 7 3}\end{array}$ & $\begin{array}{c}\text { ZSIA } \\
\mathbf{1 4 8 7 4}\end{array}$ & Mean \\
\hline Sex & male & male & female & male & male & \\
\hline SVL & 17.72 & 18.07 & 17.97 & 18.86 & 17.22 & 17.96 \\
\hline HL & 3.79 & 3.9 & 3.74 & 3.83 & 3.43 & 3.73 \\
\hline HW & 4.45 & 5.71 & 4.42 & 4.72 & 5.23 & 4.9 \\
\hline SL & 1.97 & 2.41 & 2.35 & 2.5 & 2.22 & 2.29 \\
\hline FAL & 4.48 & 3.71 & 3.8 & 4.65 & 3.55 & 4 \\
\hline LAL & 3.27 & 3.02 & 3.4 & 4.02 & 3.37 & 3.41 \\
\hline HAL & 3.81 & 3.77 & 3 & 3.86 & 3.44 & 3.57 \\
\hline FAW & 1.11 & 1.2 & 1.02 & 1.45 & 1.34 & 1.22 \\
\hline IMC & 0.45 & 0.42 & 0.44 & 0.68 & 0.55 & 0.5 \\
\hline OMC & 0.37 & 0.34 & 0.38 & 0.55 & 0.48 & 0.42 \\
\hline A-G & 5.62 & 6.55 & 6.14 & 8.53 & 7.6 & 6.88 \\
\hline FL & 6.16 & 6.43 & 7.94 & 7.94 & 6.62 & 7.01 \\
\hline TL & 10.02 & 9.13 & 10.29 & 9.67 & 9.11 & 9.64 \\
\hline FoL & 8.4 & 7.53 & 8.64 & 8.67 & 8.13 & 8.27 \\
\hline IMT & 0.58 & 0.67 & 0.54 & 0.54 & 0.51 & 0.57 \\
\hline OMT & 0.34 & 0.42 & 0.38 & 0.42 & 0.36 & 0.38 \\
\hline
\end{tabular}

mymensinghensis by its relatively larger adult size (Garg et al. 2019) and inverse U-shaped black mark above the anus for $M$. mukhlesuri whereas crescent-shaped black mark present above the anus in $M$. mymensinghensis as described by Hassan et al. (2014).

Identifying taxonomic characters to differentiate $M$. mukhlesuriand M. mymensinghensis is problematic. Both species exhibit similar extent of tibiotarsal articulation (when the hind leg is adpressed) up to the snout or between the eye and snout and a lateral stripe that also extends to near the snout. Garg et al. (2019) paid attention to the shape of terminal phalanges, though the holotype description by Hassan et al. (2014) focused on forearm width, tibial length and mark on anus. We would like to focus on five putative distinguishing characteristics (a) an inverse $U$ shape mark on the anus for $M$. mukhlesuri (vs crescent shaped mark in $M$. mymensinghensis) (Hassan et al. 2014); (b) a larger SVL in M. mukhlesuri (19.92-20.86 mm) ( $\mathrm{n}=4)$, vs. shorter $(17.22-18.86 \mathrm{~mm})(\mathrm{n}=5)$ in M. mymensinghensis, (c) Microhyla mymensinghensis has longer Tibia (TL) than Microhyla mukhlesuri, (d) Microhyla mymensinghensis has thicker fore-arm (FAW) than Microhyla mukhlesuri (Hassan et al. 2014), and (e) terminal phalanges of fourth toe tip knobbed but flattened in M. mukhlesuri (vs. knobbed but not flattened in M. mymensinghensis) 

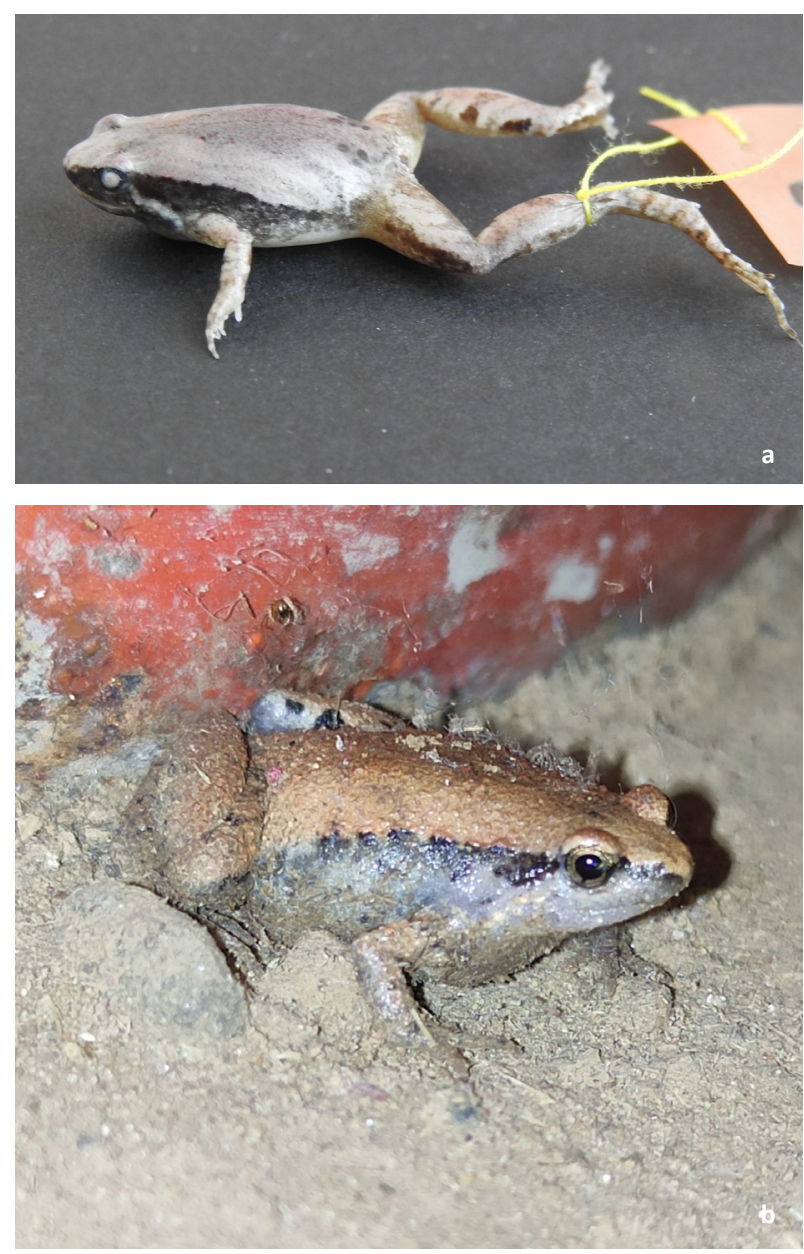

Image 2: a-Microhyla mukhlesuri (top) from Jhargram, West Bengal on $\mathbf{3 0}$ June $\mathbf{2 0 2 0}$ during evening observation, in preservation | $\mathrm{b}-M$. mymensinghensis (bottom) from Midnapore, West Bengal on 29 June 2020 during night, in life. (C) Suman Pratihar
(Garg et al. 2019) (Table 1). Based on these characters we have identified and classified the specimens examined in this study.

In addition to aforementioned described characters, we identified a few supplementary characters to differentiate two species more confidently: (a) shape of inner metacarpal tubercle elongated in $M$. mukhlesuri vs. rounded in $M$. mymensinghensis; (b) large inner metatarsal tubercle, i.e., about $0.76( \pm .08)$ $\mathrm{mm}$ in $M$. mukhlesuri vs about $0.57( \pm .06) \mathrm{mm}$ in $M$. mymensinghensis; (c) most significantly, axilla-groin distance $47 \%$ of SVL in M. mukhlesuri vs $38 \%$ of SVL in $M$. mymensinghensis. Both these species were observed co-occurring in humanized / agricultural habitats in the sampled areas (Image 3a, b).

Microhyla mukhlesuri showed differences with $M$. mymensinghenis in terms of morphology. Principal Component Analysis (PCA) for the specimens of both the species ( $M$. mukhlesuri, $n=4 ; M$. mymensinghensis, $n=5$ ) recovered two Principal Components (PC) with eigenvalues $>1.0$ that accounted for $85.8 \%$ of the total variance. PC1 explained $74.09 \%$ variance with highest loadings for A-G, TL, SVL and FoL. PC2 explained $11.71 \%$ variance with highest loadings for $A-G$, and $H W$. The remaining factors explained $14.2 \%$ of the variations. For the combined data set for both male and female projections of the factor planes 1 and 2 showed distinct clusters for the two species (Figure 1).

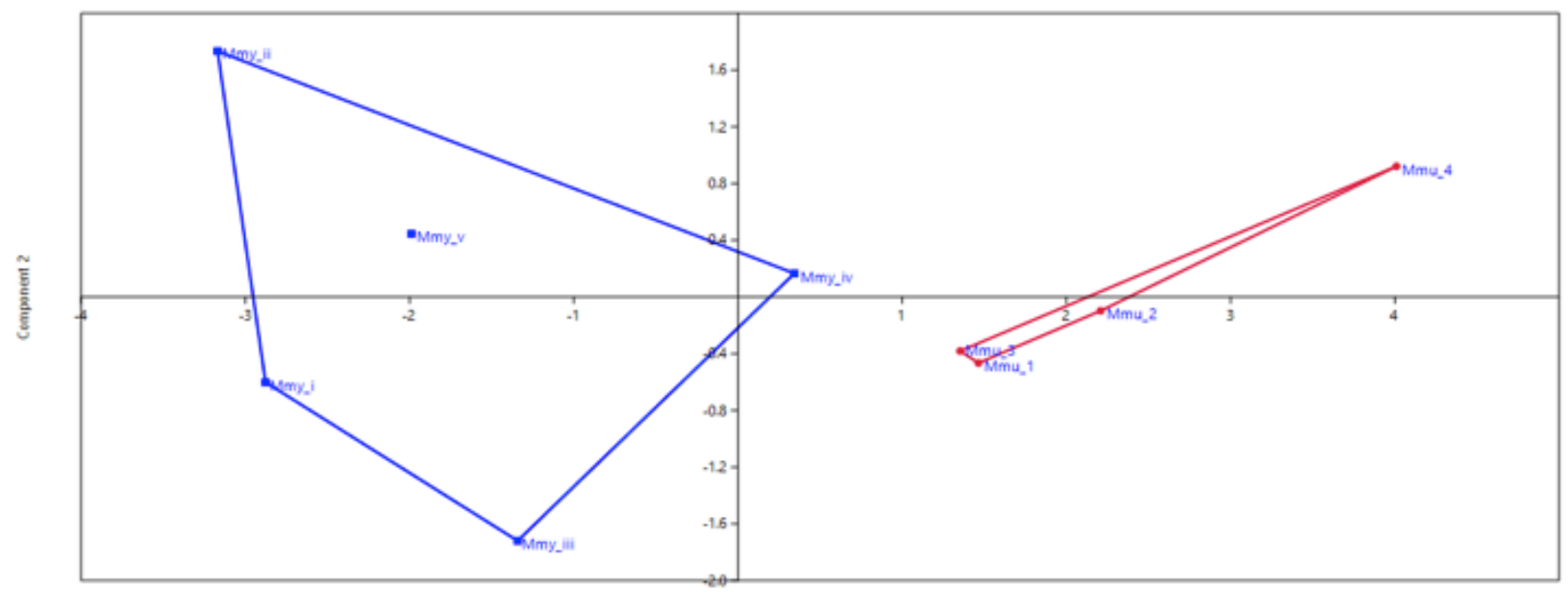

Component 1

Figure 1. Principal component analysis (PCA) Scatter plot depicting morphometric differences between Microhyla mukhlesuri and Microhyla mymensinghensis. 

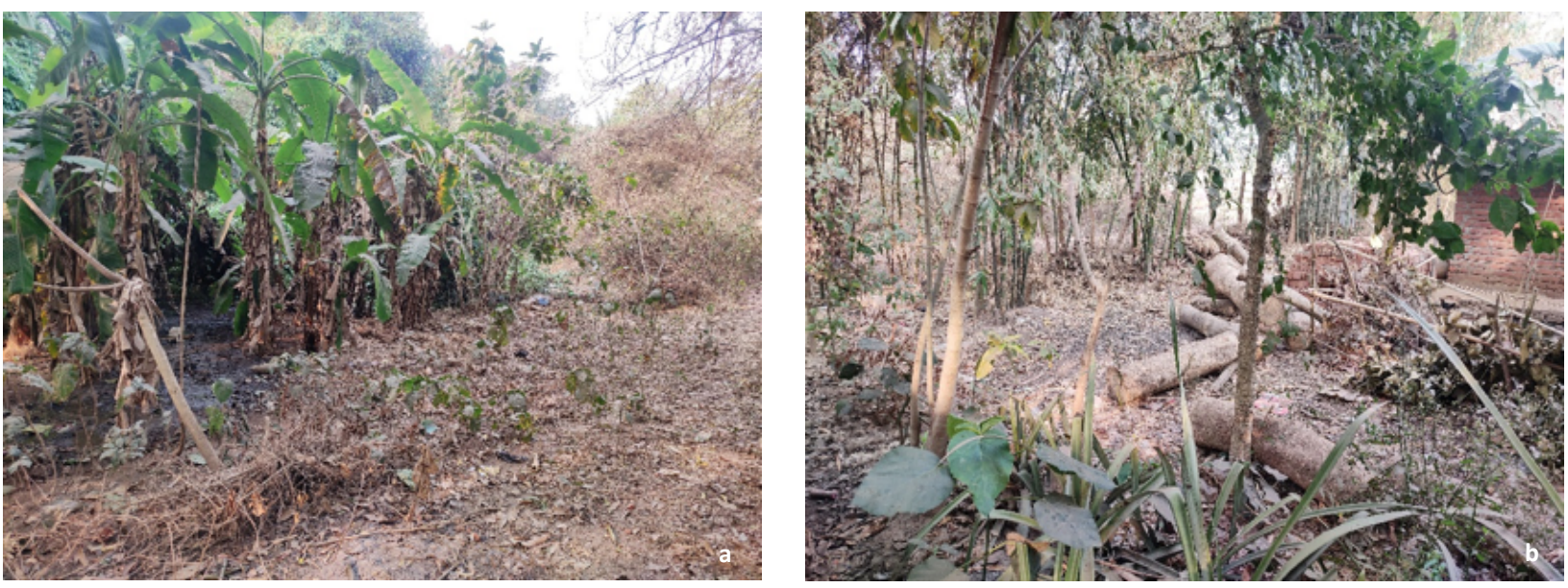

Image 3. Habitat of (a) Microhyla mukhlesuri (left) and (b) M. mymensinghensis (right). () Chandan Dandapat

Table 2. Ratios of morphometric character values for Microhyla mukhlesuri and Microhyla mymensinghensis. For character abbreviations see Materials \& Methods.

\begin{tabular}{|l|c|c|}
\hline Ratios & $\begin{array}{c}\text { Microhyla } \\
\text { mymensinghensis }\end{array}$ & Microhyla mukhlesuri \\
\hline $\mathrm{HL} / \mathrm{SVL}$ & $.21 \pm .01$ & $.22 \pm .02$ \\
\hline $\mathrm{HW} / \mathrm{SVL}$ & $.27 \pm .04$ & $.24 \pm .03$ \\
\hline $\mathrm{FAW} / \mathrm{SVL}$ & $.07 \pm 003$ & $.06 \pm .005$ \\
\hline $\mathrm{AG} / \mathrm{SVL}$ & $.38 \pm .04$ & $.47 \pm .06$ \\
\hline TL/SVL & $.54 \pm .02$ & $.51 \pm .01$ \\
\hline $\mathrm{HL} / \mathrm{HW}$ & $.76 \pm .09$ & $.89 \pm .03$ \\
\hline
\end{tabular}

\section{Discussion}

Previously, Microhyla 'ornata' like species were grossly grouped with four known species-M. mukhlesuri, M. mymensinghensis, $M$. nilphamariensis, and $M$. ornata. In 2018 two well-supported species groups were established-(1) M. mukhlesuriand M. mymensinghensis, along with $M$. fissipes from southeastern and eastern Asia, and (2) M. nilphamariensis and M. ornata, along with M. taraiensis from Nepal (Garg et al. 2018). A prominent lateral stripe extends from belly to nostril in M. mukhlesuri and M. mymensinghensis whereas a less prominent lateral stripe extends from shoulder to belly in M. nilphamariensis and M. ornata.

An inverse U shape mark on the anus for M. mukhlesuri (vs crescent shaped mark in $M$. mymensinghensis); larger SVL in M. mukhlesuri (19.92-20.86 mm) vs. shorter (17.22-18.86 mm) in M. mymensinghensis and terminal phalanges of toes knobbed but tip flattened in $M$. mukhlesuri (vs. knobbed but not flattened in $M$. mymensinghensis) are used to group the two species. In addition to this we have identified axilla-groin distance, size of metatarsal tubercle and shape of metacarpal tubercle to differentiate these two species more confidently. The PCA results reveal two different clusters on the scatterplot, representing two different species Microhyla mukhlesuri $(n=4)$ and M. mymensinghensis $(n=5)$.

Microhyla mukhlesuri has been reported only from Mizoram state in the northeast India (Garg et al. 2019). With two males and two female specimens we hereby for first time confirm the presence of Microhyla mukhlesuri from the Gangetic Plain in West Bengal, apart from Mizoram. We are optimistic about the wider distribution of Microhyla mukhlesuri in the Gangetic plains. Nevertheless we do encourage genetic studies of these Microhyla frogs, especially after finding geographic contact zones where two similar-looking, geneticallyallied congeners Microhyla mukhlesuri and $M$. mymensinghensis co-occur, throwing open necessity for further fine-scale diagnosis, preferably morphological, between them.

\section{REFERENCES}

Biju, S.D., S. Garg, R.G. Kamei \& G. Maheswaran (2019). A new Microhyla species (Anura: Microhylidae) from riparian evergreen forest in the eastern Himalayan state of Arunachal Pradesh, India. Zootaxa 4674: 100-116.

Frost, D.R. (2021). Amphibian species of the world 6.0. New York, Darrel Frost and the American Museum of Natural History.

Garg, S., A. Das, R.G. Kamei \& S.D. Biju (2018). Delineating Microhyla ornata (Anura, Microhylidae): mitochondrial DNA barcodes resolve century-old taxonomic misidentification. Mitochondrial DNA Part B, 3:2 856-861.

Garg, S., R. Suyesh, A. Das, J. Jiang, N. Wijayathilaka, A.T. Amarasinghe, F. Alhadi, K.K. Vineeth, N.A. Aravind, G. Senevirathne, M. Meegaskumbura \& S.D. Biju (2019). Systematic revision of Microhyla (Microhylidae) frogs of South Asia: a molecular, morphological, and acoustic assessment. Vertebrate Zoology 69: 1-71. 
Hasan, M., M.M. Islam, M. Kuramoto, A. Kurabayashi \& M. Sumida (2014). Description of two new species of Microhyla (Anura: Microhylidae) from Bangladesh. Zootaxa 3755: 401-418.

Howlader, M.S., A.A. Nair \& J. Merilä (2016). A new species of frog (Anura: Dicroglossidae) discovered from the mega city of Dhaka. PLoS ONE 11: e0149597. https://doi.org/10.1371/journal. pone.0149597

Poyarkov Jr., N.A., V.A. Gorin, T. Zaw, V.D. Kretova, S.S. Gogoleva, P. Pawangkhanant \& J. Che (2019). On the road to Mandalay: contribution to the Microhyla Tschudi, 1838 (Amphibia: Anura: Microhylidae) fauna of Myanmar with description of two new species. Zoological Research 40(4): 244.

Yuan, Z.Y., C. Suwannapoom, F. Yan, J.R. Poyarkov, N. Nguyen, S.N. Chen, H.M. Chomdej, S. Murphy \& J. Che (2016). Red river barrier and Pleistocene climatic fluctuation shaped the genetic structure of $M$. fissipes group complex (Anura: Microhylidae) in southern China and Indochina. Current Zoology 62: 531-543. 
Dr. Albert G. Orr, Griffith University, Nathan, Australia

Dr. Sameer Padhye, Katholieke Universiteit Leuven, Belgium

Dr. Nancy van der Poorten, Toronto, Canada

Dr. Kareen Schnabel, NIWA, Wellington, New Zealand

Dr. R.M. Sharma, (Retd.) Scientist, Zoological Survey of India, Pune, India

Dr. Manju Siliwal, WILD, Coimbatore, Tamil Nadu, India

Dr. G.P. Sinha, Botanical Survey of India, Allahabad, India

Dr. K.A. Subramanian, Zoological Survey of India, New Alipore, Kolkata, India

Dr. P.M. Sureshan, Zoological Survey of India, Kozhikode, Kerala, India

Dr. R. Varatharajan, Manipur University, Imphal, Manipur, India

Dr. Eduard Vives, Museu de Ciències Naturals de Barcelona, Terrassa, Spain

Dr. James Young, Hong Kong Lepidopterists' Society, Hong Kong

Dr. R. Sundararaj, Institute of Wood Science \& Technology, Bengaluru, India

Dr. M. Nithyanandan, Environmental Department, La Ala Al Kuwait Real Estate. Co. K.S.C., Kuwait

Dr. Himender Bharti, Punjabi University, Punjab, India

Mr. Purnendu Roy, London, UK

Dr. Saito Motoki, The Butterfly Society of Japan, Tokyo, Japan

Dr. Sanjay Sondhi, TITLI TRUST, Kalpavriksh, Dehradun, India

Dr. Nguyen Thi Phuong Lien, Vietnam Academy of Science and Technology, Hanoi, Vietnam

Dr. Nitin Kulkarni, Tropical Research Institute, Jabalpur, India

Dr. Robin Wen Jiang Ngiam, National Parks Board, Singapore

Dr. Lional Monod, Natural History Museum of Geneva, Genève, Switzerland.

Dr. Asheesh Shivam, Nehru Gram Bharti University, Allahabad, India

Dr. Rosana Moreira da Rocha, Universidade Federal do Paraná, Curitiba, Brasil

Dr. Kurt R. Arnold, North Dakota State University, Saxony, Germany

Dr. James M. Carpenter, American Museum of Natural History, New York, USA

Dr. David M. Claborn, Missouri State University, Springfield, USA

Dr. Kareen Schnabel, Marine Biologist, Wellington, New Zealand

Dr. Amazonas Chagas Júnior, Universidade Federal de Mato Grosso, Cuiabá, Brasil

Mr. Monsoon Jyoti Gogoi, Assam University, Silchar, Assam, India

Dr. Heo Chong Chin, Universiti Teknologi MARA (UiTM), Selangor, Malaysia

Dr. R.J. Shiel, University of Adelaide, SA 5005, Australia

Dr. Siddharth Kulkarni, The George Washington University, Washington, USA

Dr. Priyadarsanan Dharma Rajan, ATREE, Bengaluru, India

Dr. Phil Alderslade, CSIRO Marine And Atmospheric Research, Hobart, Australia

Dr. John E.N. Veron, Coral Reef Research, Townsville, Australia

Dr. Daniel Whitmore, State Museum of Natural History Stuttgart, Rosenstein, Germany.

Dr. Yu-Feng Hsu, National Taiwan Normal University, Taipei City, Taiwan

Dr. Keith V. Wolfe, Antioch, California, USA

Dr. Siddharth Kulkarni, The Hormiga Lab, The George Washington University, Washington,

D.C., USA

Dr. Tomas Ditrich, Faculty of Education, University of South Bohemia in Ceske

Budejovice, Czech Republic

Dr. Mihaly Foldvari, Natural History Museum, University of Oslo, Norway

Dr. V.P. Uniyal, Wildlife Institute of India, Dehradun, Uttarakhand 248001, India

Dr. John T.D. Caleb, Zoological Survey of India, Kolkata, West Bengal, India

Dr. Priyadarsanan Dharma Rajan, Ashoka Trust for Research in Ecology and the Environment (ATREE), Royal Enclave, Bangalore, Karnataka, India

\section{Fishes}

Dr. Neelesh Dahanukar, IISER, Pune, Maharashtra, India

Dr. Topiltzin Contreras MacBeath, Universidad Autónoma del estado de Morelos, México

Dr. Heok Hee Ng, National University of Singapore, Science Drive, Singapore

Dr. Rajeev Raghavan, St. Albert's College, Kochi, Kerala, India

Dr. Robert D. Sluka, Chiltern Gateway Project, A Rocha UK, Southall, Middlesex, UK

Dr. E. Vivekanandan, Central Marine Fisheries Research Institute, Chennai, India

Dr. Davor Zanella, University of Zagreb, Zagreb, Croatia

Dr. A. Biju Kumar, University of Kerala, Thiruvananthapuram, Kerala, India

Dr. Akhilesh K.V., ICAR-Central Marine Fisheries Research Institute, Mumbai Research

Centre, Mumbai, Maharashtra, India

Dr. J.A. Johnson, Wildlife Institute of India, Dehradun, Uttarakhand, India

\section{Amphibians}

Dr. Sushil K. Dutta, Indian Institute of Science, Bengaluru, Karnataka, India

Dr. Annemarie Ohler, Muséum national d'Histoire naturelle, Paris, France

\section{Reptiles}

Dr. Gernot Vogel, Heidelberg, Germany

Dr. Raju Vyas, Vadodara, Gujarat, India

Dr. Pritpal S. Soorae, Environment Agency, Abu Dubai, UAE.

Prof. Dr. Wayne J. Fuller, Near East University, Mersin, Turkey

Prof. Chandrashekher U. Rivonker, Goa University, Taleigao Plateau, Goa. India

Dr. S.R. Ganesh, Chennai Snake Park, Chennai, Tamil Nadu, India

Dr. Himansu Sekhar Das, Terrestrial \& Marine Biodiversity, Abu Dhabi, UAE
Birds

Dr. Hem Sagar Baral, Charles Sturt University, NSW Australia

Dr. Chris Bowden, Royal Society for the Protection of Birds, Sandy, UK

Dr. Priya Davidar, Pondicherry University, Kalapet, Puducherry, India

Dr. J.W. Duckworth, IUCN SSC, Bath, UK

Dr. Rajah Jayapal, SACON, Coimbatore, Tamil Nadu, India

Dr. Rajiv S. Kalsi, M.L.N. College, Yamuna Nagar, Haryana, India

Dr. V. Santharam, Rishi Valley Education Centre, Chittoor Dt., Andhra Pradesh, India

Dr. S. Balachandran, Bombay Natural History Society, Mumbai, India

Mr. J. Praveen, Bengaluru, India

Dr. C. Srinivasulu, Osmania University, Hyderabad, India

Dr. K.S. Gopi Sundar, International Crane Foundation, Baraboo, USA

Dr. Gombobaatar Sundev, Professor of Ornithology, Ulaanbaatar, Mongolia

Prof. Reuven Yosef, International Birding \& Research Centre, Eilat, Israel

Dr. Taej Mundkur, Wetlands International, Wageningen, The Netherlands

Dr. Carol Inskipp, Bishop Auckland Co., Durham, UK

Dr. Tim Inskipp, Bishop Auckland Co, Durham, UK

Dr. V. Gokula, National College, Tiruchirappalli, Tamil Nadu, India

Dr. Arkady Lelej, Russian Academy of Sciences, Vladivostok, Russia

Dr. Simon Dowell, Science Director, Chester Zoo, UK

Dr. Mário Gabriel Santiago dos Santos, Universidade de Trás-os-Montes e Alto Douro,

Quinta de Prados, Vila Real, Portugal

Dr. Grant Connette, Smithsonian Institution, Royal, VA, USA

Dr. M. Zafar-ul Islam, Prince Saud Al Faisal Wildlife Research Center, Taif, Saudi Arabia

Mammals

Dr. Giovanni Amori, CNR - Institute of Ecosystem Studies, Rome, Italy

Dr. Anwaruddin Chowdhury, Guwahati, India

Dr. David Mallon, Zoological Society of London, UK

Dr. Shomita Mukherjee, SACON, Coimbatore, Tamil Nadu, India

Dr. Angie Appel, Wild Cat Network, Germany

Dr. P.O. Nameer, Kerala Agricultural University, Thrissur, Kerala, India

Dr. Ian Redmond, UNEP Convention on Migratory Species, Lansdown, UK

Dr. Heidi S. Riddle, Riddle's Elephant and Wildlife Sanctuary, Arkansas, USA

Dr. Karin Schwartz, George Mason University, Fairfax, Virginia.

Dr. Lala A.K. Singh, Bhubaneswar, Orissa, India

Dr. Mewa Singh, Mysore University, Mysore, India

Dr. Paul Racey, University of Exeter, Devon, UK

Dr. Honnavalli N. Kumara, SACON, Anaikatty P.O., Coimbatore, Tamil Nadu, India

Dr. Nishith Dharaiya, HNG University, Patan, Gujarat, India

Dr. Spartaco Gippoliti, Socio Onorario Società Italiana per la Storia della Fauna "Giuseppe

Altobello", Rome, Italy

Dr. Justus Joshua, Green Future Foundation, Tiruchirapalli, Tamil Nadu, India

Dr. H. Raghuram, The American College, Madurai, Tamil Nadu, India

Dr. Paul Bates, Harison Institute, Kent, UK

Dr. Jim Sanderson, Small Wild Cat Conservation Foundation, Hartford, USA

Dr. Dan Challender, University of Kent, Canterbury, UK

Dr. David Mallon, Manchester Metropolitan University, Derbyshire, UK

Dr. Brian L. Cypher, California State University-Stanislaus, Bakersfield, CA

Dr. S.S. Talmale, Zoological Survey of India, Pune, Maharashtra, India

Prof. Karan Bahadur Shah, Budhanilakantha Municipality, Kathmandu, Nepal

Dr. Susan Cheyne, Borneo Nature Foundation International, Palangkaraja, Indonesia

Dr. Hemanta Kafley, Wildlife Sciences, Tarleton State University, Texas, USA

\section{Other Disciplines}

Dr. Aniruddha Belsare, Columbia MO 65203, USA (Veterinary)

Dr. Mandar S. Paingankar, University of Pune, Pune, Maharashtra, India (Molecular)

Dr. Jack Tordoff, Critical Ecosystem Partnership Fund, Arlington, USA (Communities)

Dr. Ulrike Streicher, University of Oregon, Eugene, USA (Veterinary)

Dr. Hari Balasubramanian, EcoAdvisors, Nova Scotia, Canada (Communities)

Dr. Rayanna Hellem Santos Bezerra, Universidade Federal de Sergipe, São Cristóvão, Brazil

Dr. Jamie R. Wood, Landcare Research, Canterbury, New Zealand

Dr. Wendy Collinson-Jonker, Endangered Wildlife Trust, Gauteng, South Africa

Dr. Rajeshkumar G. Jani, Anand Agricultural University, Anand, Gujarat, India

Dr. O.N. Tiwari, Senior Scientist, ICAR-Indian Agricultural Research Institute (IARI), New

Delhi, India

Dr. L.D. Singla, Guru Angad Dev Veterinary and Animal Sciences University, Ludhiana, India

Dr. Rupika S. Rajakaruna, University of Peradeniya, Peradeniya, Sri Lanka

Dr. Bahar Baviskar, Wild-CER, Nagpur, Maharashtra 440013, India

Reviewers 2018-2020

Due to pausity of space, the list of reviewers for 2018-2020 is available online.
The opinions expressed by the authors do not reflect the views of the Journal of Threatened Taxa, Wildlife Information Liaison Development Society, Zoo Outreach Organization, or any of the partners. The journal, the publisher, the host, and the partners are not responsible for the accuracy of the political boundaries shown in the maps by the authors.

\footnotetext{
Print copies of the Journal are available at cost. Write to:

The Managing Editor, JoTT,

c/o Wildlife Information Liaison Development Society,

No. 12, Thiruvannamalai Nagar, Saravanampatti - Kalapatti Road,

Saravanampatti, Coimbatore, Tamil Nadu 641035, India

ravi@threatenedtaxa.org
} 


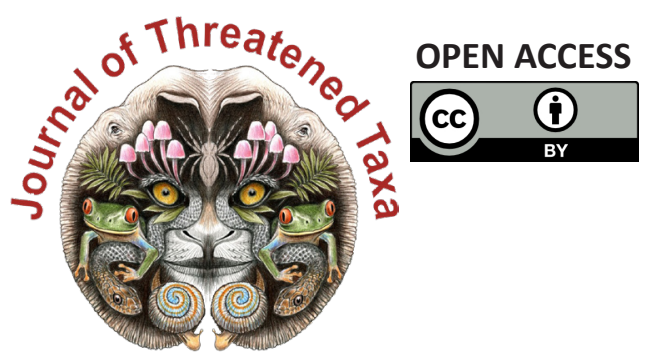

www.threatenedtaxa.org

The Journal of Threatened Taxa (JoTT) is dedicated to building evidence for conservation globally by publishing peer-reviewed articles online every month at a reasonably rapid rate at www.threatenedtaxa.org. All articles published in JoTT are registered under Creative Commons Attribution 4.0 International License unless otherwise mentioned. JoTT allows allows unrestricted use, reproduction, and distribution of articles in any medium by providing adequate credit to the author(s) and the source of publication.

\section{ISSN $0974-7907$ (Online) | ISSN $0974-7893$ (Print)}

\section{October 2021 | Vol. 13 | No. 12 | Pages: 19675-19886 \\ Date of Publication: 26 October 2021 (Online \& Print) DOI: 10.11609/jott.2021.13.12.19675-19886}

Articles

Roosting habits and habitats of the Indian Flying Fox Pteropus medius Temminck, 1825 in the northern districts of Tamil Nadu, India

- M. Pandian \& S. Suresh, Pp. 19675-19688

Diversity and distribution of avifauna at Warathenna-Hakkinda Environmental Protection Area in Kandy, Sri Lanka

- Dinelka Thilakarathne, Tithira Lakkana, Gayan Hirimuthugoda, Chaminda Wijesundara \& Shalika Kumburegama, Pp. 19689-19701

Grass species composition in tropical forest of southern India

- M. Ashokkumar, S. Swaminathan \& R. Nagarajan, Pp. 19702-19713

\section{Communications}

Habitat use and conservation threats to Wild Water Buffalo Bubalus arnee (Mammalia: Artiodactyla: Bovidae) in Koshi Tappu Wildlife Reserve, Nepal

- Reeta Khulal, Bijaya Neupane, Bijaya Dhami, Siddhartha Regmi, Ganesh Prasad Tiwari \& Manita Parajuli, Pp. 19714-19724

Get my head around owls: people perception and knowledge about owls of Andaman Islands

- Shanmugavel Sureshmarimuthu, Santhanakrishnan Babu, Nagaraj Rajeshkumar \& Honnavalli Nagaraj Kumara, Pp. 19725-19732

Abundance and diversity of threatened birds in Nangal Wetland, Punjab, India - Rajwinder Kaur \& Onkar Singh Brraich, Pp. 19733-19742

Evaluation of fish diversity and abundance in the Kabul River with comparisons between reaches above and below Kabul City, Afghanistan

- Ugyen Kelzang, Ahmad Farid Habibi \& Ryan J. Thoni, Pp. 19743-19752

New record of Myrmarachne melanocephala MacLeay, 1839 (Araneae: Salticidae) from Jharkhand, India and biogeographical implications of the co-occurrence of its ant model Tetraponera rufonigra Jerdon, 1851

- Rahul Kumar, Mirtunjay Sharma \& Ajay Kumar Sharma, Pp. 19753-19761

Diversity of spiders (Arachnida: Araneae) and the impact of pruning in Indian sandalwood plantations from Karnataka, India

-S. Padma 1 \& R. Sundararaj, Pp. 19762-19772

New records of cheilostome Bryozoa from the eastern coast of India encrusting on the exoskeleton of live horseshoe crabs of Indian Sundarbans

- Swati Das, Maria Susan Sanjay, Basudev Tripathy, C. Venkatraman \& K.A. Subramanian, Pp. 19773-19780

On the pteridophytes of Bherjan-Borajan-Padumoni Wildlife Sanctuary, Assam, India - Pranjal Borah \& Jayanta Barukial, Pp. 19781-19790

Population status of Heritiera fomes Buch.-Ham., a threatened species from Mahanadi Mangrove Wetland, India

- Sudam Charan Sahu, Manas Ranjan Mohanta \& N.H. Ravindranath, Pp. 19791-19798

Additions to the lichenized and lichenicolous fungi of Jammu \& Kashmir from Kishtwar High Altitude National Park

- Vishal Kumar, Yash Pal Sharma, Siljo Joseph, Roshinikumar Ngangom \& Sanjeeva Nayaka, Pp. 19799-19807

\section{Short Communications}

Is release of rehabilitated wildlife with embedded lead ammunition advisable? Plumbism in a Jaguar Panthera Onca (Mammalia: Carnivora: Felidae), survivor of gunshot wounds - Eduardo A. Díaz, Carolina Sáenz, E. Santiago Jiménez, David A. Egas \& Kelly Swing, Pp. 19808-19812

New record of the Sewing Needle Zipper Loach Paracanthocobitis linypha Singer \& Page, 2015 (Teleostei: Cypriniformes: Nemacheilidae) from the Chindwin drainage of Manipur, India

- Yumnam Rameshori, Yengkhom Chinglemba \& Waikhom Vishwanath, Pp. 19813-19817

Field identification characters to diagnose Microhyla mukhlesuri from closely related M. mymensinghensis (Amphibia: Microhylidae) and range extension of $M$. mukhlesuri up to West Bengal State, India

- Suman Pratihar \& Kaushik Deuti, Pp. 19818-19823
First report of Scipinia horrida (Stål) (Heteroptera: Reduviidae) from Assam, with comments on related genus Irantha Stål

- Anjana Singha Naorem, Santana Saikia, Anandita Buragohain, Rubina Azmeera Begum, Swapnil S. Boyane \& Hemant V. Ghate, Pp. 19824-19830

Flesh fly (Diptera: Sarcophagidae): male terminalia, diversity and expanded geographical distribution from India

- Kanholi Sreejith, Shuvra Kanti Sinha, Santanu Mahato \& Edamana Pushpalatha, Pp. 1983119836

Checklist of moths (Heterocera) of Tadong, Sikkim, India

- Prayash Chettri, Yuki Matsui, Hideshi Naka \& Archana Tiwari, Pp. 19837-19848

New distribution records of Begonia L., B. murina Craib and B. poilanei Kiew (Begoniaceae: Cucurbitales) for Laos

- Phongphayboun Phonepaseuth, Phetlasy Souladeth, Soulivanh Lanorsavanh, Shuichiro Tagane, Thyraphon Vongthavone \& Keooudone Souvannakhoummane Pp. 19849-19854

Notes

A recent sighting of the Stripe-backed Weasel Mustela strigidorsa (Mammalia: Carnivora: Mustelidae) in Hkakabo Razi Landscape, Myanmar

- Sai Sein Lin Oo, Tun Tun, Kyaw Myo Naing \& Paul Jeremy James Bates, Pp. 19855-19859

Are the uplifted reef beds in North Andaman letting nesting Olive Ridley Sea Turtle Lepidochelys olivacea stranded?

- Nehru Prabakaran, Anoop Raj Singh \& Vedagiri Thirumurugan, Pp. 19860-19863

First record of the orb-weaving spider Araneus tubabdominus Zhu \& Zhang, 1993 (Araneae: Araneidae) from India

- Souvik Sen, John T.D. Caleb \& Shelley Acharya, Pp. 19864-19866

The genus Catapiestus Perty, 1831 (Coleoptera: Tenebrionidae: Cnodalonini) from Arunachal Pradesh with one new record to India

- V.D. Hegde \& Sarita Yadav, Pp. 19867-19869

Rediscovery and extended distribution of Indigofera santapaui Sanjappa (Leguminosae: Papilionoideae) from the states of Maharashtra and Gujarat, India

- Kumar Vinod Chhotupuri Gosavi, Sanjay Gajanan Auti, Sharad Suresh Kambale \& Munivenkatappa Sanjappa, Pp. 19870-19873

Additional distribution records of Ceropegia anjanerica, an endemic and 'Endangered' lantern flower of the northern Western Ghats, India

- Samir Shrikant Maity, Ajay Natha Gangurde, Sharad Suresh Kambale, Avinash Ramchandra Gholave, Avinash Asraji Adsul, Ganesh Babaso Pawar \& Kumar Vinod Chhotupuri Gosavi, Pp. 19874-19877

Notes on the extended distribution of Impatiens megamalayana, a recently described balsam in Western Ghats, India

- Anoop P. Balan \& A.J. Robi, Pp. 19878-19883

Book Review

A look over on the scented tree of India (Santalum album - S. Suresh Ramanan \& A. Arunachalam, Pp. 19884-19886
Publisher \& Host
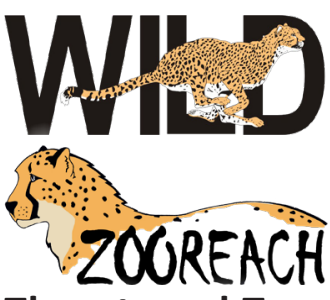

Threatened Taxa 